\title{
Changes in the lichen biota of the Lions Rump area, King George Island, Antarctica, over the last 20 years
}

\author{
Maria Olech $^{1,2} \cdot$ Agnieszka Słaby $^{1}$
}

Received: 10 October 2014/Revised: 10 December 2015/Accepted: 11 December 2015/Published online: 16 January 2016

(C) The Author(s) 2016. This article is published with open access at Springerlink.com

\begin{abstract}
Climate changes observed in recent years in the maritime Antarctic have affected the tundra vegetation, including plant communities in which lichens are a dominant component. The results of comparative studies (1988 and 1990 vs. 2007 and 2008) on the dynamics of the lichen biota within the Antarctic Specially Protected Area No. 151 (King George Island, Antarctica) minimally influenced by human impact, are presented. This long-term experiment is aimed at determining the trends and rate of changes on lichen biota induced by climate warming and rapid deglaciation. The most significant changes affecting the lichen biota have taken place in the forefield of a glacier and on the young moraines where in the second period of studies three species (Polyblastia gothica, Thelenella kerguelena, Thelocarpon cyaneum) were not refound. There was also a reduction in the number of other sites for some species (e.g. Leptogium puberulum, Staurothelle gelida) caused by substrate desiccation. On the other hand, there was an increase in the range of pioneering species (e.g. Bacidia chrysocolla, Caloplaca johnstonii, Candelariella aurella, Lecanora dispersa) on young moraines recently uncovered by the retreating glacier. The smallest changes were observed on the cliff rocks near penguin colonies.
\end{abstract}

Agnieszka Słaby

a.slaby@uj.edu.pl

1 Department of Polar Research and Documentation, Institute of Botany, Jagiellonian University, Kopernika 27, 31-501 Cracow, Poland

2 Department of Antarctic Biology, Institute of Biochemistry and Biophysics, Polish Academy of Sciences, Ustrzycka 10/12, 02-141 Warsaw, Poland
Keywords Lichen biota - Biodiversity - ASPA No. 151 . Climate change $\cdot$ Maritime Antarctica

\section{Introduction}

As a consequence of recent regional climate warming across the Western Antarctic Peninsula region, the extent and permanence of which have been unprecedented in recent decades (King and Harangozo 1998; Vaughan et al. 2003; Turner et al. 2005), a rapid deglaciation of the land has been witnessed (Vaughan and Doake 1996; Birkenmajer 2002; Vaughan 2006). This region has been one of the fastest warming places on the Earth (Smith et al. 1996; King and Harangozo 1998; Convey et al. 2009; Turner et al. 2009). This implies changes in the natural environment and its wildlife (Convey 2006; Olech 2010), including lichens, which play an important, sometimes dominant, role in Antarctic terrestrial ecosystems.

Lichens have specific characteristics not found among other groups of organisms, such as a slow growth rate, longevity and an ability to colonize pioneer habitats, as well as an exceptional sensitivity to changes in the habitat. These features attracted the interest of scientists for many years, but our knowledge of these organisms is still incomplete, particularly with regard to the polar regions.

The aim of this paper was to analyse the dynamics of the lichen biota of an area undergoing rapid deglaciation, namely the Antarctic Specially Protected Area (ASPA) No. 151, Lions Rump, King George Island (Antarctica). Therefore, the current species composition, their distribution as compared to historical data, habitat preferences as well as their reactions to the changes taking place (warming, deglaciation, ecological succession, substantial desiccation of the substrate) were investigated. ASPA No. 151 
was selected as the study area due to its physiographic distinction, lack of anthropogenic impact and the detailed knowledge gained from previous lichenological studies in 1988 and 1990 (Olech 1996, 2004). In order to determine the changes in the lichen biota, comparative studies were carried out in the summer seasons of 2007 and 2008.

This paper, which raises the issue of changes in the lichen biota resulting from deglaciation and warming of the land, is one of the first such attempts undertaken in the Antarctic.

\section{Study area}

ASPA No. 151 is located on the southern coast of King George Bay, King George Island, in the South Shetland Islands, within the area bounded by the following coordinates: lat. $62^{\circ} 07^{\prime} 48^{\prime \prime}$ and $62^{\circ} 08^{\prime} 16^{\prime \prime} \mathrm{S}$ and long. $58^{\circ} 09^{\prime} 17^{\prime \prime}$ and $58^{\circ} 09^{\prime} 15^{\prime \prime} \mathrm{W}$ (Fig. 1). The area was originally designated as a Site of Special Scientific Interest No. 34 (Olech 1996) in Recommendation XVI-2 (1991, SSSI No. 34) after a proposal by Poland on the grounds that it contains diverse biota and geological features, and is a representative example of the terrestrial, limnological and littoral habitats of the maritime Antarctic. This area was intended to be a comparative area with regard to ASPA No. 128 (former SSSI No. 8), being similar to the latter but not influenced by the human impact. In 2002, SSSI No. 34 was renamed as an Antarctic Specially Protected Area Lions Rump, ASPA No. 151. The geological and climatic characteristics of the area are briefly described in Olech (1996).

The recent rapid regional warming has caused a retreat of the White Eagle Glacier located in the study area (Angiel 2010), the ice wall shifting by c. $500 \mathrm{~m}$ between 1998 and 2009 (Angiel 2010; Olech 2010).

\section{Materials and methods}

Field studies were carried out during two summer seasons in 2007 and 2008. The research covered the entire area within the ASPA No. 151 boundaries, as well as the neighbouring areas recently freed from ice cover as a result of the glacier's retreat. As in previous studies (Olech 1996), lichen biota was listed according to a cartographic method based on a grid of squares $250 \times 250 \mathrm{~m}$. Within these squares, a series of permanent research sites were selected and their geographical coordinates recorded using a GARMIN eTrex GPS in order to facilitate comparative studies in the future (Olech and Słaby 2012).

At every site, all lichen species were recorded from various types of substrate such as dead mosses, soil and rocks. The samples were only collected when needed to confirm identifications in the laboratory; common species were recorded without sampling. The list of lichen species identified during the present study was compared with corresponding data from the former studies (years 1988 and 1990). The nomenclature was mainly adopted from Øvstedal and Lewis Smith (2001) and Olech (2004), with
Fig. 1 Map of King George Island with location of Antarctic Specially Protected Area (ASPA) No. 151

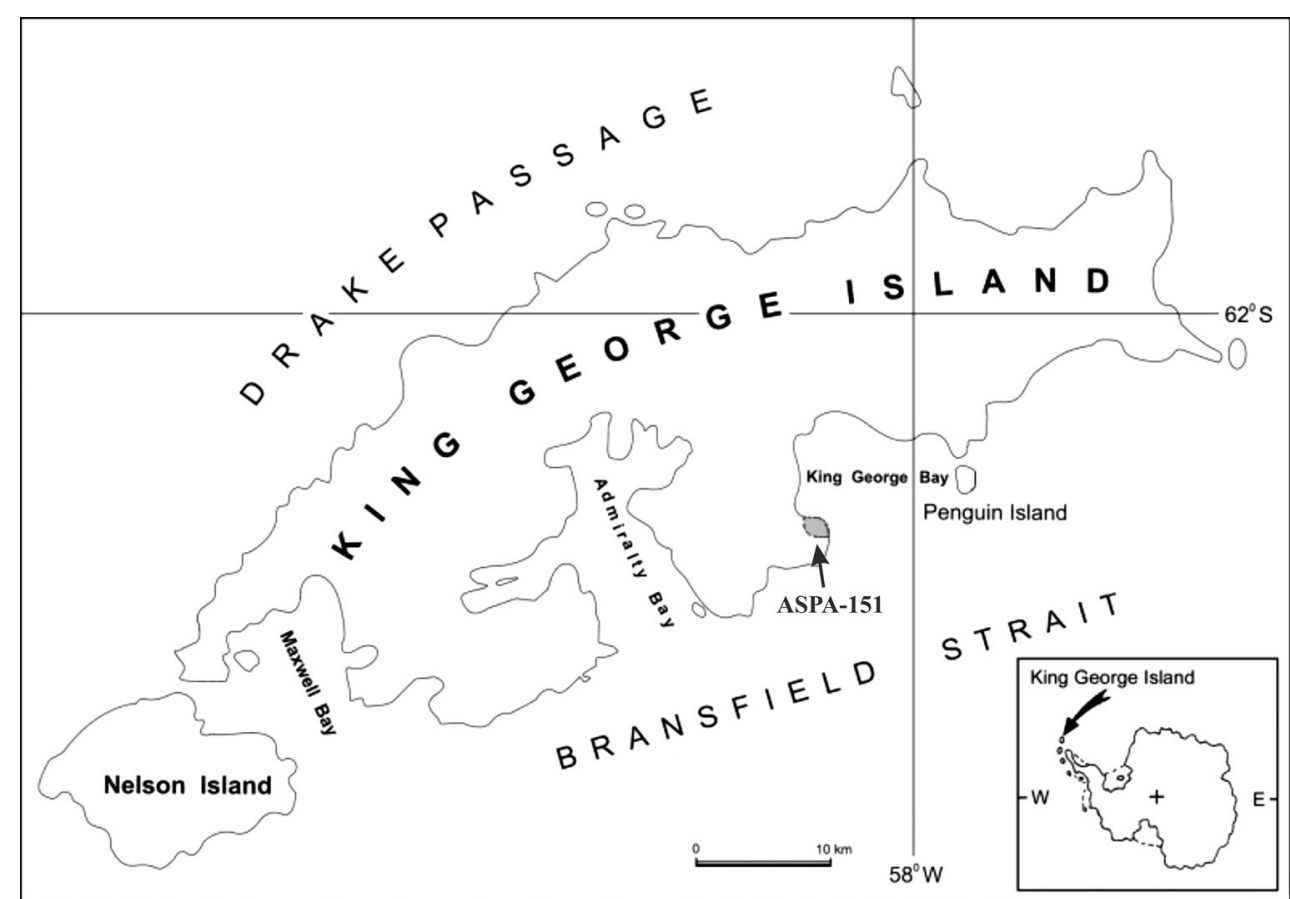


additional help from the publications of Søchting et al. (2004), Galloway et al. (2005), Olech and Czarnota (2009) and Osyczka et al. (2010). Collected specimens have been deposited in the Lichenological Herbarium of the Institute of Botany, Jagiellonian University (KRA-L).

\section{Results}

\section{General characteristics of the Lichen Biota}

During the field studies carried out in ASPA No. 151 in 2007 and 2008, 140 species of lichenized fungi were observed, the large majority of which are widespread, or even common species in the maritime Antarctic.

In order to evaluate the changes which have taken place in the lichen biota of the study area, current data were compared with historical data recorded c. 20 years previously. The diversity of lichenized fungi found in 2007 and 2008 (139 taxa) differed from that recorded in 1988 and 1990 (95 taxa), with numerous species not recorded before and three species that have since disappeared. Based on comparative historical and current data, the following groups of taxa were distinguished: (a) species new to the area, (b) expanding species, (c) species not refound, (d) species with a reduced range of occurrence and (e) species showing no changes.

\section{(a) Species new to ASPA No. 151}

During the present studies (2007 and 2008), 46 species new to the study area were observed; however, seven species (Bacidia chrysocolla, Caloplaca hertelii, C. insignis, C. sauronii, Massalongia olechiana, Pertusaria oculae-ranae, Placopsis antarctica) may have been overlooked in these studies, since they have only been described as new to science since 2000 (Søchting et al. 2004; Galloway et al. 2005; Olech and Czarnota 2009; Alstrup and Søchting 2011). Furthermore, recent taxonomic studies have enabled the determination of Aspicilia aquatica, Buellia falklandica, Caloplaca schofieldii, Collema tenax, Tephromela eatoni and T. minor, as well as providing updated synonyms (e.g. Lecanora semipallida, Protopannaria austro-orcadensis). New species observed in ASPA No. 151, not found in 1988 and 1990 (Olech 1996, 2004), included Acarospora badiofusca, Bellemerea alpina, Buellia darbishirei, B. illaetabilis, B. papillata, Caloplaca athallina, C. isidioclada, C. schofieldii, Eiglera flavida, Lecanora griseosorediata, Lecidea andersonii, L. spheniscidarum, Lepraria alpina, L. caerulescens, Parmeliella austroshetlandica, Pertusaria coccodes, P. pseudoculata, Placidium lachneoides, Porpidia austroshetlandica, Psoroma ciliatum, P. saccharatum, Rhizocarpon badioatrum,
$R$. grande, $R$. polycarpum, Rinodina cf. occulta, Tremolecia atrata, Trimmatothelopsis antarctica, Umbilicaria decussata, U. kappenii and Verrucaria aethiobola. It should be noted that $P$. lachneoides and T. antarctica are extremely rare in Antarctica.

\section{(b) Expanding species}

This group includes those species which were confirmed during the present studies (2007 and 2008), and for which an evident increase in the number of their sites was recorded, implying that their frequency of occurrence class has clearly changed from very rare and rare to scattered, frequent or even common. Such species (e.g. Caloplaca sublobulata, C. johnstonii, Candelariella aurella, Lecanora dispersa) are the first to colonize rocks and boulders exposed as a result of the glacier's retreat.

An increase in the number of sites supporting nitrophilous species, such as Physconia muscigena, was also observed near birds' nests. The phenomenon is related to the general increase in populations of some flying birds since the establishment of ASPA No. 151 (Korczak-Abshire et al. 2011).

Bacidia chrysocolla (Olech and Czarnota 2009), mistakenly listed as Bacidia trachona in previous papers, has significantly expanded its range. This species, found on young moraines, belongs to an interesting ecological group of organisms which grow on lower surfaces and undersides of rocks (hypolithic lichens). During the present study (2007 and 2008), abundant populations on numerous sites were found.

\section{(c) Species not refound}

In spite of thorough field searches in 2007 and 2008, some species observed during previous studies (1988 and 1990) were not refound, especially Polyblastia gothica and growing on it Thelocarpon cyaneum which are now extinct within ASPA No. 151. Both species require a substrate thoroughly saturated with water and occur most frequently on slopes wetted by water. Over the last years, as a result of deglaciation and the retreat of the White Eagle Glacier for more than $500 \mathrm{~m}$ to the north (Angiel 2010), the area in the proximity of habitats of both species ceased to be supplied with water, which led to their drying out. A similar phenomenon of extinction for these species has been observed in other areas of King George Island (Olech 2010).

It should be noted that due to critical taxonomic revisions it has been necessary to exclude several species as being mistakenly listed in previous papers, namely Bacidia trachona, Cladonia lepidophora, Leprocaulon subalbicans, Pannaria hookeri, Pertusaria dactylina and Rinodina turfacea. 
(d) Species with a reduced range of occurrence

Species reducing their range of occurrence in the study area included Leptogium puberulum, its frequency changing from common to scattered due to a decrease in suitable habitats. This species is often found near late snow patches, in melt-water runnels, on wet or moist mosses. Several other species (e.g. Staurothele gelida) are similarly affected due to the decline in such habitats, mainly due to substrate desiccation.

\section{(e) Species showing no changes}

Most taxa recorded in the study area have no observed tendency to increase or reduce the number of sites in which they occur. They are mainly ornithocoprophilous lichens (e.g. Caloplaca regalis, C. hookeri), and their occurrence is limited to sites on seaside rocks in the proximity of large penguin colonies. Expansions of these species have smaller chances due to their relatively stable habitat in maritime areas which were the earliest ones freed from ice in the study area.

\section{Discussion}

On the Western Antarctic Peninsula, recent rapid regional warming has been observed over the last 60 years (Turner et al. 2005). The retreat of glaciers shows direct responses to the climate changes (Angiel 2010). The climate changes have a significant impact on terrestrial ecosystems, as exemplified by vascular plants (Fowbert and Lewis Smith 1994; Lewis Smith 2001), bryophytes and microbiota (Wynn-Williams 1996; Lewis Smith 2001). This paper discusses the results of experiments on lichen biota dynamics in the forefield of a glacier during a 20-year period. Comparative studies on lichen biota were carried out within ASPA No. 151 (Antarctic Special Protected Areas) in 1988 and 1990 and again in 2007 and 2008. The most significant changes affecting the lichen biota have taken place on young moraines located in the interior, in the proximity of the areas recently uncovered as a result of the retreat of the White Eagle Glacier between 1988 and 2008, when both perennial and seasonal snow patches disappeared. The whole area has substantially dried out, the changes in the duration of the snow cover and in the humidity of the substrate are being responsible for the changes in the diversity of lichen species. Tendencies to reduce their frequency of occurrence, and even to disappear, are observed in the case of species linked to the following types of habitats: wet or moist stony soil, meltwater runnels, moist mosses and rock ledges. Examples of species linked to these habitats are $P$. gothica and $T$. cyaneum which had disappeared by 2008 , as well as retreating taxa, such as L. puberulum and S. gelida, which decreased their range of occurrence. Continuous deglaciation uncovering new areas from the ice has resulted in increased colonization by pioneer lichen species, especially $C$. johnstonii, C. aurella, L. dispersa and B. chrysocola, as well as C. athallina, C. isidioclada, E. flavida and P. lachneoides. The smallest qualitative and quantitative changes in the lichen biota were observed in the maritime cliff rocks and in the proximity of large penguin colonies, where welldeveloped and stable communities of ornithocoprophilous lichens are found.

Acknowledgments We are grateful to colleagues from the Arctowski Station, especially those who took part in the field studies, namely Piotr Angiel, Katarzyna Chwedorzewska, Małgorzata Korczak-Abshire, Anna Gasek, also to Prof. Andrzej Massalski for language editing during preparation of this paper and to Małgorzata Matyjaszkiewicz for assistance in the map preparation. The authors would also like to thank the Chief Editor and anonymous reviewers whose constructive criticism and valuable suggestions greatly enhanced the manuscript. Special thanks to Mark R. D. Seaward for language revision.

Open Access This article is distributed under the terms of the Creative Commons Attribution 4.0 International License (http://creative commons.org/licenses/by/4.0/), which permits unrestricted use, distribution, and reproduction in any medium, provided you give appropriate credit to the original author(s) and the source, provide a link to the Creative Commons license, and indicate if changes were made.

\section{References}

Alstrup V, Søchting U (2011) Massalongia olechiana (Massalongiaceae, Peltigerales), a new lichen species from the Antarctic. Pol Polar Res 32:117-121

Angiel PJ (2010) Glaciers retreat in ASPA-151 in the period 1988-2009 (Lions Rump, King George Island, South Shetlands, Antarctica). In: International polar year, Oslo science conference 9-12 June 2010. Abstract No. 382347

Birkenmajer K (2002) Retreat of Ecology Glacier, Admiralty Bay, King George Island (South Shetland Islands, West Antarctica) 1956-2001. Bull Pol Acad Sci Earth Sci 50:5-19

Convey P (2006) Antarctic climate change and its influences on terrestrial ecosystems. In: Bergstrom DM, Convey P, Huiskes AHL (eds) Trends in Antarctic terrestrial and limnetic ecosystems: Antarctica as a global indicator. Springer, Dordrecht, pp 253-272

Convey P, Bindschadler R, di Prisco G, Fahrbach E, Gutt J, Hodgson DA, Mayewski PA, Summerhayes CP, Turner J, ACCE Consortium (2009) Antarctic climate change and the environment. Antarct Sci 21:541-563. doi:10.1017/ S0954102009990642

Fowbert JA, Lewis Smith RI (1994) Rapid population increases in native vascular plants in the Argentine Islands, Antarctic Peninsula. Arct Alp Res 26:290-296

Galloway DJ, Lewis Smith RI, Quilhot W (2005) A new species of Placopis (Agyriaceae: Ascomycota) from Antarctica. Lichenologist 37:321-327

King JC, Harangozo SA (1998) Climate change in the western Antarctic Peninsula since 1945: observations and possible causes. Ann Glaciol 27:571-575 
Korczak-Abshire M, Angiel PJ, Wierzbicki G (2011) Records of white-rumped sandpiper (Calidris fuscicollis) on the South Shetland Islands. Polar Rec 47:262-267. doi:10.1017/ S0032247410000665

Lewis Smith RI (2001) Plant colonization response to climate change in the Antarctic. Folia Fac Sci Nat Univ Masarykianae Brunensis Geographia 25:19-33

Olech M (1996) Lichenological assessment of the Cape Lions Rump, King George Island, South Shetlands; a baseline for monitoring biological changes. Pol Polar Res 15:111-130

Olech M (2004) Lichens of King George Island. The Institute of Botany of the Jagiellonian University, Krakow, Antarctica

Olech M (2010) Responses of Antarctic tundra ecosystem to climate change and human activity. Pap Glob Change IGBP 17:43-52. doi:10.2478/v10190-010-0004-4

Olech M, Czarnota P (2009) Two new Bacidia (Ramalinaceae, lichenized Ascomycota) from Antarctica. Pol Polar Res 30:339-346

Olech M, Słaby A (2012) The lichen biota of Antarctic Specially Protected Area No. 151, Lions Rump (King George Island). In: Lipnicki L (ed) Lichen protection-Lichen protected species. Sonar Literacki, Gorzów Wlkp.-Lubsko, pp 67-80

Osyczka P, Kukwa M, Olech M (2010) Notes on the lichen genus Lepraria from maritime (South Shetlands) and continental (Schirmacher and Bunger Oases) Antarctica. Polar Biol 33:627-634

Øvstedal DO, Lewis Smith RI (2001) Lichens of Antarctica and South Georgia. Cambridge University Press, Cambridge

Smith RC, Stammerjohn SE, Baker KS (1996) Surface air temperature variations in the western Antarctic Peninsula region. In:
Ross RM, Hoffman EE, Quetin L (eds) Foundations for ecological research west of the Antarctic Peninsula. American Geophysical Union, Washington, pp 105-121

Søchting U, Øvstedal DO, Sancho LG (2004) The lichens of Hurd Peninsula, Livingston Island, South Shetlands, Antarctica. In: Döbbeler P, Rambold G (eds) Contributions to Lichenology. Festschrift in Honour of Hannes Hertel. Bibl Lichenol 88. J. Cramer in der Gebrüder Borntraeger Verlagsbuchhandlung, Berlin-Stuttgart, pp 607-658

Turner J, Colwell SR, Marshall GJ, Lachlan-Cope TA, Carleton AM, Jones PD, Lagun V, Reid PA, Iagovkina S (2005) Antarctic climate change during the last 50 years. Int $\mathrm{J}$ Climatol 25:279-294

Turner J, Bindschadler R, Convey P, di Prisco G, Fahrbach E, Gutt J, Hodgson D, Mayewski P, Summerhayes C (eds) (2009) Antarctic climate change and the environment. Scientific Committee on Antarctic Research Report, Cambridge, p 526

Vaughan DG (2006) Trends in melting conditions on the Antarctic Peninsula and their implications for ice sheet mass balance. Arct Antarct Alp Res 38:147-152

Vaughan DG, Doake CSM (1996) Recent atmospheric warming and retreat of ice shelves on the Antarctic Peninsula. Nature 379:328-331

Vaughan DG, Marshall GJ, Connolley WM, Parkinson C, Mulvaney R, Hodgson DA, King JC, Pudsey CJ, Turner J (2003) Recent rapid regional climate warming on the Antarctic Peninsula. Clim Change 60:243-274. doi:10.1023/A:1026021217991

Wynn-Williams DD (1996) Response of pioneer soil microalgal colonists to environmental change in Antarctica. Microb Ecol $31: 177-188$ 